\title{
PENGUATAN USAHA KECIL MENENGAH MELALUI PROGRAM TANGGUNG JAWAB SOSIAL PERUSAHAAN (Studi pada PT INKA Persero)
}

\author{
Tatik Mulyati ${ }^{1)}$, Saraswati Budi Utami ${ }^{2)}$ \\ ${ }^{1.2)}$ Fakultas Ekonomi, Universitas Merdeka Madiun \\ email: tatikmulyati@unmer-madiun.ac.id
}

\begin{abstract}
One of CSR PT INKA (Persero) programme is partnership that increase small business in order to be a resilient and independent business. PT INKA (Persero) is one of BUMN that bounded with obligation to implement Corporate Social Responsibility (CSR) programme as an actualization company's activity. In its implementation, the CSR partnership programme has not effective yet by its planning, implementation or restraint. The human resources's problem, nothing assistancing and monitoring its implementation, can be reduced if implemented by other support including a university. The aim of this research are: 1) Understanding the implementation of CSR partnership programme had done by PT INKA (Persero); 2) Understanding an obstacle in CSR partnership programme; 3) Understanding the effectivity of implementation CSR partnership programme. The respondent is a micro enterpreneur that guidanced by PT INKA (Persero). The population are 424 partners that spread out in Bakorwil Madiun and samples are 88 partners that taken by Cluster Convenience Sampling. Data was collected by interview, questionnaire and documentation. Using Wilcoxon Match Pairs test to know output's effectivity with comparing before and after receiving funds's programme of CSR. The results, there are significant differences between before and after receiving revolving funds as CSR's programme. It shows that CSR partnership's programme are effective for strengthening economic community especially partner of PT INKA (Persero).
\end{abstract}

Keywords: small and medium enterprises, CSR, partnership's programme, empowerment's economic

\begin{abstract}
Abstrak
Kata Kunci: Salah satu program CSR PT INKA (Persero) adalah kemitraan yang meningkatkan usaha kecil agar menjadi bisnis yang tangguh dan mandiri. PT INKA (Persero) adalah salah satu BUMN yang terikat dengan kewajiban untuk melaksanakan program Corporate Social Responsibility (CSR) sebagai kegiatan aktualisasi perusahaan. Dalam implementasinya, program kemitraan CSR belum efektif dengan perencanaan, implementasi atau pengendaliannya. Masalah sumber daya manusia, tidak ada yang membantu dan memantau pelaksanaannya, dapat dikurangi jika diimplementasikan oleh dukungan lain termasuk universitas. Tujuan dari penelitian ini adalah: 1) Memahami implementasi program kemitraan CSR yang telah dilakukan oleh PT INKA (Persero); 2) Memahami hambatan dalam program kemitraan CSR; 3) Memahami efektivitas implementasi program kemitraan CSR. Responden adalah pengusaha mikro yang dibimbing oleh PT INKA (Persero). Populasi adalah 424 mitra yang tersebar di Bakorwil Madiun dan sampel adalah 88 mitra yang diambil oleh Cluster Convenience Sampling. Data dikumpulkan melalui wawancara, kuesioner, dan dokumentasi. Menggunakan uji Wilcoxon Match Pairs untuk mengetahui efektivitas keluaran dengan membandingkan sebelum dan sesudah menerima dana program CSR. Hasilnya, ada perbedaan yang signifikan antara sebelum dan sesudah menerima dana bergulir sebagai program CSR. Ini menunjukkan bahwa program kemitraan CSR efektif untuk memperkuat komunitas ekonomi terutama mitra PT INKA (Persero).
\end{abstract}

Kata kunci: usaha kecil dan menengah, CSR, program kemitraan, ekonomi pemberdayaan 


\section{JURNAL EKONOMI DAN MANAJEMEN \\ P-ISSN: 2598-9022/ E-ISSN: 2598-9618 \\ Available at:}

http://e-journal.unipma.ac.id/index.php/capital

\section{A. LATAR BELAKANG}

Industri dan korporasi berperan mendorong pertumbuhan ekonomi yang sehat dengan mempertimbangkan faktor lingkungan dan masyarakat. Corporate Social Responsibility atau popular disebut CSR mencerminkan perlunya sebuah perusahaan membangun hubungan harmonis dengan masyarakat domisili sekaligus merupakan tanggung jawab perusahaan terhadap para stakeholders, terutama komunitas atau masyarakat di sekitar wilayah kerja atau operasional. Program CSR yang dilaksanakan seringkali kurang menyentuh akar permasalahan komunitas yang sesungguhnya. Perusahaan menganggap sebagai pihak yang paling memahami kebutuhan komunitas, sementara komunitas dianggap sebagai kelompok yang menderita sehingga memerlukan bantuan perusahaan. Selain itu, aktivitas CSR dilakukan semata-mata demi terciptanya reputasi perusahaan yang pasif bukan perbaikan kualitas hidup komunitas dalam jangka panjang (Hopkins, 2007).

Suatu perusahaan dapat mewujudkan CSR dengan baik apabila mampu menerapkan kewajiban secara berimbang antara kepentingan stakeholder primer dan sekunder. Stakeholder primer merupakan kelompok yang secara langsung memengaruhi kemampuan perusahaan dalam mencapai tujuan utama yaitu memberikan barang dan jasa kepada masyarakat, sedangkan stakeholder sekunder adalah semua kelompok dalam masyarakat yang dapat dipengaruhi secara langsung atau tidak langsung oleh dampak sekunder beroperasinya suatu perusahaan. CSR seyogyanya tidak hanya bergerak dalam aspek philantropy, melainkan harus merambat naik ke tingkat pemberdayaan masyarakat (community empowerment) dan harus merupakan salah satu bagian policy pihak manajemen perusahaan (Putra, 2015).

Seiring dengan perkembangan isu lingkungan global, konsep dan aplikasi Corporate Social Responsibility (CSR) semakin berkembang, termasuk di Indonesia. CSR tidak semata menjadi kewajiban sosial perusahaan, namun juga dikaitkan sebagai konsep pengembangan yang berkelanjutan (sustainable development). Perkembangan CSR di Indonesia membutuhkan perhatian semua pihak, baik pemerintah, masyarakat luas dan perusahaan. Penerapan CSR pada dasarnya diarahkan pada penguatan ekonomi rakyat yang berbasis usaha kecil dan menengah serta peningkatan kualitas SDM masyarakat melalui perbaikan sarana dan prasarana pendidikan sebagai respon dunia usaha yang melihat aspek lingkungan dan sosial sebagai peluang untuk meningkatkan daya saing serta sebagai bagian dari pengelolaan risiko menuju sustainability kegiatan usaha (Dahlia, 2012).

Perguruan tinggi dengan misi dan kompetensi yang dimiliki, diharapkan dapat membantu dalam implementasi program kemitraan CSR dengan mengisi kegiatan yang belum dilaksanakan secara efektif oleh PT INKA (Persero) yaitu pendidikan, pembimbingan, pendam- 


\section{JURNAL EKONOMI DAN MANAJEMEN \\ P-ISSN: 2598-9022/ E-ISSN: 2598-9618 \\ Available at: \\ http://e-journal.unipma.ac.id/index.php/capital}

pingan, monitoring dan evaluasi. Sistem yang baik diperlukan pada tahap perencanaan, implementasi dan pengendalian. Kompleksnya kegiatan tersebut menyebabkan semakin besar potensi permasalahan yang berarti semakin diperlukan partner untuk bekerja sama guna memaksimalkan hasil implementasi program CSR.

Dunia pendidikan pada bidang dan level tertentu dapat disesuaikan dengan kebutuhan dunia usaha termasuk kebutuhan pengusaha kecil, antara lain pengadaan aktiva tetap, SDM, pembimbingan, pendampingan dan lain-lain dengan memanfaatkan program CSR. Potensi membangun sinergi yang demikian akan memberikan hasil maksimal dalam menguatkan pengusaha kecil, sustainable corporate bagi implementator CSR serta melahirkan lembaga pendidikan yang memenuhi kebutuhan pasar kerja. Penguatan pengusaha kecil akan memberikan multiplier effect untuk penguatan ekonomi masyarakat sekitar yang akan memberikan kontribusi pada penguatan ekonomi nasional. Dalam pengembangannya, pelaku UKM sebagai cermin perekonomian masyarakat harus menjadi salah satu strategiutama pembangunan nasional yang pelaksanaannya diwujudkan secara sungguh-sungguh dengan komitmen bersama yang kuat serta didukung oleh upaya - upaya sistematis dan konseptual secara konsisten dan terus menerus dengan melibatkan semua pihak yang berkepentingan baik pemerintah, swasta, maupun masyarakat di tingkat nasional, regional, maupun lokal.

\begin{tabular}{lcr}
\multicolumn{1}{c}{ Program } & CSR & yang \\
dilaksanakan oleh & PT & INKA \\
(Persero), salah satu Badan Usaha & Bar \\
Milik Negara (BUMN) & strategis di \\
Indonesia selama ini & telah \\
dilaksanakan & sebagai & mandat \\
Pemerintah & melalui & Peraturan
\end{tabular}

Menteri Badan Usaha Milik Negara Nomor: $\quad$ PER-07/MBU/05/2015 untuk melaksanakan Program Kemitraan dan Bina Lingkungan (PKBL). Potensi besar untuk penguatan ekonomi masyarakat dapat dilakukan melalui pemberian bantuan untuk peningkatan usaha kecil. Penelitian ini akan diarahkan pada Program Kemitraan CSR, sebagaimana diamanatkan dalam peraturan yang berlaku. Terkait upaya peningkatan usaha kecil memerlukan perhatian khusus karena kompleksnya permasalahan terkait keterbatasan sumber daya manusia (SDM), ketiadaan pendampingan, hingga lemahnya monitoring pelaksanaan program.

Pelaku usaha kecil menengah (UKM) atau mitra binaan dalam program kemitraan CSR yang dilaksanakan PT INKA (Persero) sebanyak 424 pengusaha dapat memberikan gambaran bahwa potensi yang telah dikelola sangatlah besar. Oleh sebab itu harus dilaksanakan dengan baik melalui proses perencanaan, implementasi dan pengendalian yang disusun dengan melibatkan beberapa pihak terkait yakni perguruan tinggi, pemerintah daerah dan lembaga/ institusi lain sesuai kebutuhan.

Tujuan penelitian ini adalah: (1) Mengetahui implementasi program kemitraan CSR yang telah dilakukan PT INKA (Persero); (2) 


\section{JURNAL EKONOMI DAN MANAJEMEN \\ P-ISSN: 2598-9022/ E-ISSN: 2598-9618 \\ Available at: \\ http://e-journal.unipma.ac.id/index.php/capital}

Mengetahui permasalahan dalam implementasi program kemitraan CSR PT INKA Persero dan (3) Mengkaji efektifitas implementasi program kemitraan CSR yang dijalankan PT INKA Persero terhadap penguatan ekonomi masyarakat khususnya mitra binaan.

Berdasarkan permasalahan yang menjadi fokus kajian dan tujuan yang ingin dicapai, penelitian ini diharapkan dapat memberi manfaat implementasi CSR PT INKA (Persero).

Pertama, perusahaan yang menjalankan tanggungjawab sosial secara konsisten akan mendapatkan dukungan luas dari komunitas yang telah merasakan manfaat berbagai aktifitas yang dijalankan. CSR akan mendongkrak citra perusahaan, yang dalam rentang waktu panjang akan meningkatkan reputasi perusahaan. Manakala terdapat pihak-pihak tertentu yang menuduh perusahaan melakukan perilaku serta menjalankan praktek-praktek yang tidak pantas, masyarakat akan menunjukan pembelaanya. Karyawan pun akan berdiri di belakang perusahaan, membela tempat industri bekerja.

Kedua, keterlibatan dan kebanggaan karyawan. Karyawan akan merasa bangga bekerja pada perusahaan yang memiliki reputasi baik, yang secara konsisten melakukan upaya membantu meningkatkan kesejahteraan dan kualitas hidup masyarakat dan lingkungan sekitar. Kebanggan ini pada akhirnya akan menghasilkan loyalitas, sehingga karyawan merasa lebih termotivasi untuk bekerja lebih keras demi kemajuan perusahaan.
Hal ini berujung pada peningkatan kinerja dan produktivitas.

Ketiga, CSR yang dilaksanakan secara konsisten akan mampu memerbaiki dan mempererat hubungan antara perusahaan dengan stakeholders. Pelaksanaan CSR secara konsisten menunjukan bahwa perusahaan memiliki kepedulian terhadap lancarnya berbagai aktivitas dan kemajuan yang diraih. Hal ini berdampak para stakeholders senang dan nyaman dalam menjalankan hubungan dengan perusahaan.

\section{B. METODE PENELITIAN}

Lokasi penelitian adalah PT INKA (Persero) dan wilayah cakupan pelaksanaan distribusi dana bantuan permodalan program kemitraan CSR PT INKA (Persero) di Bakorwil Madiun meliputi Kabupaten dan Kota Madiun, Ngawi, Ponorogo, Magetan dan Pacitan.

Populasi penelitian adalah pengusaha mikro mitra binaan PT INKA (Persero) penerima program CSR yang tersebar di wilayah Bakorwil Madiun berjumlah sebanyak 427 orang. Mengingat penyebaran lokasi domisili responden sangat luas, maka penelitian ini menggunakan sampel yang ditentukan dengan rumus Slovin (Sanusi, 2011). Untuk meningkatkan representasi sampel, digunakan sampel sebesar 88 responden, yang diambil dari 5 wilayah berdasarkan jenis usaha yang ditentukan oleh PT INKA (Persero) yakni perdagangan dan industri.

Teknik pengambilan sampel menggunakan Cluster Convenience Sampling dengan pertimbangan luas 


\section{JURNAL EKONOMI DAN MANAJEMEN \\ P-ISSN: 2598-9022/ E-ISSN: 2598-9618 \\ Available at: \\ http://e-journal.unipma.ac.id/index.php/capital}

wilayah dan jarak sehingga Pacitan diabaikan. Sampel hanya 5 wilayah kota kabupaten yang diambil dari 6 wilayah Bakorwil Madiun, yaitu Kota dan Kabupaten Madiun, Magetan, Ngawi dan Ponorogo. Data penelitian dikumpulkan melalui beberapa teknik/ metode yaitu: metode wawancara mendalam (indepth interview), kuesioner, observasi, diskusi kelompok terfokus (FGD)/ brain storming dan dokumentasi. Data sekunder yang diteliti adalah data penerima program CSR di PT INKA Persero yang diperoleh dari pihak PT INKA yakni divisi Corporate Plan and General Affairs (manajer dan staf).

Teknik pengumpulan data dilakukan melalui observasi, wawancara dan kuesioner. Untuk menguji keabsahan data primer dilakukan triangulasi sumber data untuk cross check data primer dengan mitra dan pihak-pihak terkait. Data sekunder diperoleh dari dokumen dan profil Lokasi penelitian adalah PT INKA (Persero) dan wilayah cakupan pelaksanaan distribusi dana bantuan permodalan program kemitraan CSR PT INKA (Persero) di Bakorwil Madiun meliputi Kabupaten dan Kota Madiun, Ngawi, Ponorogo, Magetan dan Pacitan.

Populasi penelitian adalah pengusaha mikro mitra binaan PT INKA (Persero) penerima program CSR yang tersebar di wilayah Bakorwil Madiun berjumlah sebanyak 427 orang. Mengingat penyebaran lokasi domisili responden sangat luas, maka penelitian ini menggunakan sampel yang ditentukan dengan rumus Slovin
(Sanusi, 2011). Untuk meningkatkan representasi sampel, digunakan sampel sebesar 88 responden, yang diambil dari 5 wilayah berdasarkan jenis usaha yang ditentukan oleh PT INKA (Persero) yakni perdagangan dan industri.

Teknik pengambilan sampel menggunakan Cluster Convenience Sampling dengan pertimbangan luas wilayah dan jarak sehingga Pacitan diabaikan. Sampel hanya 5 wilayah kota kabupaten yang diambil dari 6 wilayah Bakorwil Madiun, yaitu Kota dan Kabupaten Madiun, Magetan, Ngawi dan Ponorogo. Data penelitian dikumpulkan melalui beberapa teknik/ metode yaitu: metode wawancara mendalam (indepth interview), kuesioner, observasi, diskusi kelompok terfokus (FGD)/ brain storming dan dokumentasi. Data sekunder yang diteliti adalah data penerima program CSR di PT INKA Persero yang diperoleh dari pihak PT INKA yakni divisi Corporate Plan and General Affairs (manajer dan staf).

Teknik pengumpulan data dilakukan melalui observasi, wawancara dan kuesioner. Untuk menguji keabsahan data primer dilakukan triangulasi sumber data untuk cross check data primer dengan mitra dan pihak-pihak terkait. Data sekunder diperoleh dari dokumen dan profil program CSR PT INKA serta mitra binaan program kemitraan PT INKA Persero atau dinas/instansi terkait sebagai mediator penyalur dalam hal ini Dinas/Kantor Koperasi.

Penelitian dilakukan dengan kombinasi penelitian survei dan studi kasus, untuk menilai efektifitas dan 


\section{JURNAL EKONOMI DAN MANAJEMEN \\ P-ISSN: 2598-9022/ E-ISSN: 2598-9618 \\ Available at: \\ http://e-journal.unipma.ac.id/index.php/capital}

mengevaluasi implementasi program kemitraan CSR. Metode analisis yang digunakan adalah analisis deskriptif, analisis kuantitatif yang didukung oleh analisis kualitatif dengan pendekatan deskriptif.

\section{Analisis Deskriptif}

Analisis Deskriptif digunakan untuk mengetahui pendapat responden dilakukan dengan analisis skala dalam hal ini menggunakan skala Likert. Teknik analisis data yang digunakan adalah teknik analisis deskriptif kuantitatif dengan menjabarkan hasil penelitian, untuk menganalisis data yang diperoleh dari hasil penelitian dengan mentabulasi data yang diperoleh melalui keterangan responden, kemudian dicari frekuensi dan persentasenya. Setelah itu disusun dalam bentuk tabel tunggal dengan menggunakan skala Likert.

\section{Analisis Kuantitatif}

Analisis kuantitatif digunakan untuk mengukur tingkat efektifitas program kemitraan CSR melalui hasil penyebaran kuesioner kepada responden. Efektivitas adalah mengukur hubungan antara hasil (realisasi) dengan potensi (target) yang ditetapkan. Pengukuran tingkat efektivitas dilakukan pada variabel input, proses dan output masingmasing indikator.

Kriteria untuk menilai efektifitas input digunakan indikator: keterlibatan/ partisipasi dalam perencanaan dan sosialisasi. Untuk menilai efektivitas proses digunakan indikator: ketepatan sasaran, ketepatan waktu distribusi, dan aktivitas pendampingan mitra, sedangkan menilai efektivitas output program digunakan indikator: kemanfaatan, produktivitas usaha mitra, tingkat pendapatan, kemandirian, dan keberlanjutan (sustainable) usaha.

Instrumen dalam kuesioner diukur dengan skala Likert. Skor terendah adalah 1 dan skor tertinggi adalah 5 untuk setiap pernyataan. Pedoman pemberian skor masingmasing alternatif jawaban adalah : (SS) Sangat Setuju diberi skor 5; (S) Setuju diberi skor 4; (N) Cukup Setuju/Netral diberi skor 3; (KS) Kurang Setuju diberi skor 2 dan (TS) Tidak Setuju diberi skor 1, artinya setiap kejadian yang digambarkan pada pernyataan sama sekali tidak pernah terjadi. Pedoman pemberian skor dipergunakan untuk pertanyaan yang bersifat positif.

Teknik analisis untuk menguji efektifitas CSR program kemitraan menggunakan uji Wilcoxon Match Pairs (paired sample $t$ test) yang menunjukkan perbedaan antara kondisi ekonomi mitra sebelum dan sesudah menerima bantuan dana bergulir program kemitraan CSR PT INKA (Persero). Kriteria yang digunakan untuk menilai efektifitas program adalah menggunakan efektifitas output yang mencakup indikator: kapasitas produksi/operasi, laba, modal, omzet penjualan, volume penjualan, dan jumlah tenaga kerja mitra.

\section{HASIL DAN PEMBAHASAN}

Pelaksanaan Program CSR Di PT INKA (Persero) sejak tahun 1993 yang dikenal dengan Program 


\section{JURNAL EKONOMI DAN MANAJEMEN \\ P-ISSN: 2598-9022/ E-ISSN: 2598-9618 \\ Available at: \\ http://e-journal.unipma.ac.id/index.php/capital}

Kemitraan dan Bina Lingkungan (PKBL). Ketentuan tentang pelaksanaan PKBL di lingkungan BUMN khususnya di PT INKA (Persero) diatur melalui Peraturan Direksi yang telah diperbarui dan disempurnakan dengan Nomor: PER03/INKA/2015 tentang Program Kemitraan dan Bina Lingkungan. Program Kemitraan merupakan bentuk kepedulian perusahaan terhadap masyarakat yang berada di sekitar PT INKA (Persero) maupun mitra binaan bertujuan untuk meningkatkan pendapatan dan taraf hidup masyarakat, menciptakan dan memperluas lapangan kerja, mewujudkan usaha kecil yang tangguh dan mandiri, menciptakan kemitraan antara perusahaan dengan pengusaha kecil dan koperasi. Sedangkan Program Bina Lingkungan bertujuan untuk memberdayakan dan mengembangkan kondisi sosial ekonomi masyarakat serta bantuan untuk pendidikan, pelatihan, pemagangan, pemasaran, maupun bentuk bantuan lain yang terkait dengan upaya peningkatan kapasitas mitra binaan.

Prosedur pengajuan usulan pinjaman dana bergulir PKBL adalah dengan mengisi formulir yang telah disediakan oleh PT INKA Persero. Selanjutnya formulir tersebut diserahkan kepada Direksi cq SM Sekretariat Protokoler \& PKBL melalui Dinas/Kantor Koperasi kabupaten/kota masing-masing mitra untuk dievaluasi dan diverifikasi. Setelah dinyatakan layak oleh Dinas Koperasi, selanjutnya diproses oleh PT INKA (Persero). Sebagai jaminan pinjaman, mitra menyerahkan agunan sebagai ikatan moril yang nilainya minimal $10 \%$ (sepuluh persen) di atas nilai pinjaman. Persyaratan tentang agunan ini diatur melalui Peraturan Direksi tahun 2004.

Perkembangan jumlah mitra binaan PT INKA (Persero) dari awal tahun 1993 sampai dengan tahun 2014 secara akumulasi sebanyak 1.512 mitra, yang terdiri dari 1.141 mitra bergerak di sektor industri dan 371 mitra di sektor perdagangan. Tahun 2015 jumlah mitra binaan bertambah 65 mitra di sektor industri dan 5 mitra di sektor perdagangan sehingga berjumlah 1.582 mitra yang terdiri dari 1.206 mitra bergerak di sektor industri dan 376 bergerak di sektor perdagangan yang tersebar di wilayah Madiun.

\section{Analisis Deskriptif}

Analisis data terlebih dahulu dilakukan secara deskriptif untuk memeroleh gambaran mengenai tendensi atau kecenderungan penilaian responden terhadap variabelvariabel penelitian yang meliputi efektifitas input, efektifitas proses dan efektifitas output. Selanjutnya dilakukan perhitungan distribusi frekwensi dan rata-rata (mean) jumlah jawaban responden.

Jumlah mitra binaan sampai dengan tahun 2015 yang benar-benar masih dibina sebanyak 427 mitra. Dalam penelitian ini, penyaluran bantuan kepada mitra binaan dibatasi selama tahun 2012 - 2015 di wilayah Madiun yakni Kota dan Kabupaten Madiun, Kabupaten Magetan, Kabupaten Ngawi dan Kabupaten Ponorogo sejumlah 176 mitra. Selanjutnya diambil responden 


\section{JURNAL EKONOMI DAN MANAJEMEN \\ P-ISSN: 2598-9022/ E-ISSN: 2598-9618 \\ Available at: \\ http://e-journal.unipma.ac.id/index.php/capital}

sebagai sampel sebanyak 88 mitra dengan rincian sesuai kegiatan usaha sebagai berikut:

Tabel 1. Jenis Usaha Mitra Binaan Di Wilayah Madiun Tahun 2012-2015

\begin{tabular}{|c|c|c|c|}
\hline \multirow{2}{*}{ Kode } & \multirow{2}{*}{ Jenis Usaha } & \multicolumn{2}{|c|}{ Jumlah } \\
\hline & & Unit & $\%$ \\
\hline & Makanan dan minuman & 47 & 53 \\
\hline $\begin{array}{l}\text { A } \\
\text { B }\end{array}$ & $\begin{array}{l}\text { Bengkel, besi, aluminium, } \\
\text { mebel aluminium, kaca }\end{array}$ & 11 & 13 \\
\hline $\mathrm{C}$ & $\begin{array}{l}\text { Perdagangan: Mracang, jual } \\
\text { mainan anak, gerabah }\end{array}$ & 3 & 3 \\
\hline D & Mebel Kayu & 7 & 8 \\
\hline $\mathrm{E}$ & $\begin{array}{l}\text { Konveksi, batik, jahit, border, } \\
\text { batik jumput }\end{array}$ & 7 & 8 \\
\hline $\mathrm{F}$ & $\begin{array}{l}\text { Bahan bangunan : gypsum, } \\
\text { beton }\end{array}$ & 3 & 3 \\
\hline G & $\begin{array}{l}\text { Kerajinan kulit : sepatu, tas, } \\
\text { sabuk }\end{array}$ & 5 & 6 \\
\hline $\mathrm{H}$ & $\begin{array}{l}\text { Industri kreatif : sulam songket, } \\
\text { anyaman plastik }\end{array}$ & 1 & 1 \\
\hline I & $\begin{array}{l}\text { Lain-lain : Penyamakan kulit, } \\
\text { tusuk sate }\end{array}$ & 4 & 5 \\
\hline & & 88 & 100 \\
\hline
\end{tabular}

Sumber: Data primer diolah, 2016

Dari Tabel 1, dapat diketahui bahwa penyaluran dana CSR paling banyak diberikan kepada mitra binaan yang bergerak dalam jenis usaha makanan dan minuman. Penyaluran paling sedikit diberikan kepada kelompok industri kreatif. Hal tersebut terjadi karena pengajuan pinjaman dari kelompok industri kreatif sangat minim. Untuk mengetahui lebih jelas alokasi dana CSR kepada mitra binaan, jenis usaha dikelompokkan ke dalam kelompok industri dan perdagangan sebagaimana ketentuan PT INKA Persero pada Tabel 2 berikut:
Tabel 2

Usaha Industri dan Perdagangan Mitra Binaan Di Wilayah Madiun

Tahun 2012-2015

\begin{tabular}{|c|l|c|c|}
\hline Kode & \multirow{2}{*}{ Jenis Usaha } & \multicolumn{2}{|c|}{ Jumlah } \\
\cline { 3 - 4 } & & Total & $\%$ \\
\hline A & Industri (A,B,E,G,H,I) & 75 & 85 \\
\hline B & Perdagangan (C,D,F) & 13 & 15 \\
\cline { 2 - 4 } & & 88 & 100 \\
\hline
\end{tabular}

Sumber: Data primer diolah, 2016

Dari Tabel 2, jenis usaha industri lebih banyak mendapatkan alokasi pinjaman dana CSR Program Kemitraan PT INKA Persero daripada jenis usaha perdagangan. Hal tersebut disebabkan pengajuan usulan banyak didominasi pelaku usaha di bidang industri.

\section{Analisis Efektifitas Input}

Analisis ini bertujuan untuk mengetahui distribusi jawaban responden terhadap indikator efektifitas input yang meliputi: (1) Sosialisasi program kemitraan PT INKA apakah memberikan kejelasan hak dan kewajiban bagi mitra; (2) Mitra dilibatkan atau tidak dalam proses penyaluran dana CSR melalui pertemuan dengan pihak PT INKA; dan (3) Sosialisasi program memberikan manfaat atau tidak bagi mitra binaan. Distribusi jawaban responden pada variabel efektifitas input disajikan dalam tabel 3: 


\section{JURNAL EKONOMI DAN MANAJEMEN \\ P-ISSN: 2598-9022/ E-ISSN: 2598-9618 \\ Available at: \\ http://e-journal.unipma.ac.id/index.php/capital}

Tabel 3

Distribusi Jawaban Responden untuk Efektifitas Input

\begin{tabular}{|c|c|c|c|c|c|c|c|c|c|c|c|}
\hline \multirow{3}{*}{ Indikator } & \multicolumn{10}{|c|}{ Jawaban Responden } & \multirow{3}{*}{$\begin{array}{l}\text { Me } \\
\text { an }\end{array}$} \\
\hline & \multicolumn{2}{|c|}{ SS } & \multicolumn{2}{|r|}{$\mathbf{S}$} & \multicolumn{2}{|c|}{ CS } & \multicolumn{2}{|c|}{ KS } & \multicolumn{2}{|c|}{ TS } & \\
\hline & $\mathbf{F}$ & $\%$ & $\mathbf{F}$ & $\%$ & $\mathbf{F}$ & $\%$ & $\mathbf{F}$ & $\%$ & $\mathbf{F}$ & $\%$ & \\
\hline $\begin{array}{l}\text { Sosialisasi program kemitraan } \\
\text { memberikan kejelasan hak dan } \\
\text { kewajiban bagi mitra }\end{array}$ & 3 & 3,4 & 69 & 78,4 & 15 & 17,1 & 1 & 1,2 & 0 & 0 & 3,84 \\
\hline $\begin{array}{l}\text { Mitra dilibatkan dalam proses } \\
\text { penyaluran dana CSR }\end{array}$ & 2 & 2,3 & 72 & 81,8 & 12 & 13,6 & 2 & 2,3 & 0 & 0 & 3,84 \\
\hline $\begin{array}{l}\text { Sosialisasi program bermanfa-at } \\
\text { bagi mitra binaan }\end{array}$ & 10 & 11,4 & 71 & 80,7 & 6 & 6,8 & 1 & 1,2 & 0 & 0 & 4,03 \\
\hline
\end{tabular}

\section{Sumber: Data primer diolah, 2016}

Deskripsi responden pada Tabel 3 menunjukkan bahwa sosialisasi program kemitraan tentang kejelasan hak dan kewajiban mitra memeroleh respon dengan nilai rata-rata sebesar 3,84 yang berarti tanggapan mitra cenderung setuju bahwa sosialisasi program kemitraan tentang hak dan kewajiban diperlukan oleh mitra. Hal ini dimaksudkan agar mitra binaan PT INKA Persero memahami tentang hak dan kewajiban sehingga kesalahpahaman bisa dihindarkan. Keterlibatan mitra dalam proses penyaluran dana CSR memeroleh respon dengan nilai rata-rata sebesar 3,84 yang berarti tanggapan mitra cenderung setuju bahwa mitra binaan perlu dilibatkan dalam proses penyaluran dana CSR dari PT INKA agar ada keterbukaan/ transparansi dalam proses penyaluran. Sosialisasi program memberi manfaat bagi mitra memperoleh respon dengan nilai rata-rata sebesar 4,01 yang berarti tanggapan mitra sebagai responden cenderung setuju bahwa mitra binaan perlu memeroleh sosialisasi program dari PT INKA agar mengetahui dan memiliki arahan atau panduan dalam pemanfaatan dana CSR dari PT INKA Persero sehingga tidak disalahgunakan dalam pemanfaatannya.

Dengan demikian berdasarkan nilai rata-rata (mean) efektifitas input sebesar 3,91 berarti bahwa tanggapan mitra sebagai responden cenderung setuju bahwa input/masukan terkait penyaluran dana CSR dari PT INKA Persero efektif.

\section{Analisis Efektifitas Proses}

Efektifitas proses pengajuan usulan pinjaman dana CSR dari PT INKA Persero dapat dilihat dari indikator: (1) Kemudahan syarat administrasi; (2) Ketepatan sasaran penyaluran bantuan kepada mitra; (3) Kecepatan/kelancaran penyaluran bantuan; (4) Manfaat pelatihan untuk pengembangan usaha mitra; (5) Manfaat pendampingan untuk pengembangan usaha mitra; 6) Akses komunikasi kepada mitra binaan selama periode/masa pinjaman; dan (7) Kesempatan konsultasi tentang pengembangan usaha mitra selama periode pinjaman. 


\section{JURNAL EKONOMI DAN MANAJEMEN \\ P-ISSN: 2598-9022/ E-ISSN: 2598-9618 \\ Available at: \\ http://e-journal.unipma.ac.id/index.php/capital}

Berdasarkan indikator tersebut, hasil survei tentang proses pengajuan usulan pinjaman dana CSR dapat disajikan pada tabel 4 .

Tabel 4

Distribusi Jawaban RespondenUntuk Efektifitas Proses

\begin{tabular}{|c|c|c|c|c|c|c|c|c|c|c|c|}
\hline \multirow{3}{*}{ Indikator } & \multicolumn{10}{|c|}{ Jawaban Responden } & \multirow[t]{3}{*}{ Mean } \\
\hline & \multicolumn{2}{|c|}{ SS } & \multicolumn{2}{|c|}{$\mathbf{S}$} & \multicolumn{2}{|c|}{$\mathrm{CS}$} & \multicolumn{2}{|c|}{ TS } & \multicolumn{2}{|c|}{ STS } & \\
\hline & $\mathbf{F}$ & $\%$ & $\mathbf{F}$ & $\%$ & $\mathbf{F}$ & $\%$ & $\mathbf{F}$ & $\%$ & $\mathbf{F}$ & $\%$ & \\
\hline Kemudahan syarat administrasi & 8 & 9,1 & 65 & 73,9 & 15 & 17,1 & 0 & 0 & 0 & 0 & 3,92 \\
\hline $\begin{array}{l}\text { Ketepatan sasaran penyaluran } \\
\text { dana }\end{array}$ & 14 & 15,9 & 61 & 69,3 & 11 & 12,5 & 2 & 2,3 & 0 & 0 & 3,99 \\
\hline Kelancaran penyaluran dana & 17 & 19,3 & 51 & 58,0 & 19 & 21,6 & 1 & 1,14 & 0 & 0 & 3,96 \\
\hline $\begin{array}{l}\text { Manfaat pelatihan untuk } \\
\text { pengembangan }\end{array}$ & 4 & 4,6 & 56 & 63,6 & 13 & 14,8 & 12 & 13,6 & 3 & 3,4 & 3,53 \\
\hline $\begin{array}{l}\text { Manfaat pendampingan bagi } \\
\text { mitra }\end{array}$ & 8 & 9,1 & 56 & 63,6 & 8 & 9,1 & 14 & 15,9 & 2 & 2,3 & 3,62 \\
\hline Akses komunikasi kepada mitra & 6 & 6,8 & 60 & 68,2 & 21 & 23,9 & 1 & 1,14 & 0 & 0 & 3,81 \\
\hline $\begin{array}{l}\text { Kesempatan konsultasi pada PT } \\
\text { INKA }\end{array}$ & 4 & 4,6 & 61 & 69,3 & 20 & 22,7 & 2 & 2,3 & 1 & 1,4 & 3,74 \\
\hline Efektifitas Proses & & & & & & & & & & & 3,76 \\
\hline
\end{tabular}

Deskripsi responden pada Tabel 4 menunjukkan bahwa indikator kemudahan syarat administrasi memeroleh respon dengan nilai ratarata sebesar 3,92 yang berarti tanggapan mitra sebagai responden cenderung setuju bahwa syarat administrasi yang diterapkan oleh PT INKA mudah dipenuhi oleh mitra binaan. Indikator ketepatan sasaran penyaluran dana memeroleh respon dengan nilai rata-rata sebesar 3,99 yang berarti tanggapan responden cenderung setuju bahwa sasaran penyaluran dana oleh PT INKA pada mitra binaan sudah tepat/ tidak salah sasaran. Indikator kelancaran penyaluran dana memeroleh respon dengan nilai rata-rata sebesar 3,96 yang berarti tanggapan responden cenderung setuju bahwa penyaluran dana oleh PT INKA pada mitra binaan lancar dan tanpa hambatan yang berarti. Indikator manfaat pelatihan untuk pengembangan memeroleh respon dengan nilai rata- rata sebesar 3,53 yang berarti tanggapan responden cenderung setuju bahwa pelatihan untuk pengembangan usaha oleh PT INKA dirasakan bermanfaat bagi mitra binaan. Indikator manfaat pendampingan bagi mitra memeroleh respon dengan nilai rata-rata sebesar 3,62 yang berarti tanggapan responden cenderung setuju bahwa pendampingan oleh PT INKAbagi mitra binaan dirasakan bermanfaat. Indikator akses komunikasi kepada mitra memeroleh respon dengan nilai rata-rata sebesar 3,81 yang berarti tanggapan responden cenderung setuju bahwa akses komunikasi oleh PT INKA pada mitra binaan mudah dan lancar. Indikator kesempatan konsultasi memeroleh respon dengan nilai rata-rata sebesar 3,74 yang berarti tanggapan responden cenderung setuju bahwa kesempatan konsultasi dari PT INKA pada mitra binaan terbuka/ tidak ada kesulitan ataupun hambatan. 


\section{JURNAL EKONOMI DAN MANAJEMEN \\ P-ISSN: 2598-9022/ E-ISSN: 2598-9618 \\ Available at: \\ http://e-journal.unipma.ac.id/index.php/capital}

Dengan demikian berdasarkan nilai rata-rata (mean) efektifitas proses sebesar 3,76 berarti bahwa tanggapan mitra sebagai responden cenderung setuju bahwa proses yang berkaitan dengan penyaluran dana CSR dari PT INKA Persero efektif, mudah, tepat, lancar dan tidak bertele-tele. Persyaratan administratif telah diatur melalui Peraturan Direksi.

\section{Analisis Efektifitas Output}

Efektifitas output setelah memeroleh pinjaman dana CSR dari PT INKA Persero dapat dilihat dari indikator: (1) Usaha menjadi lebih mandiri; (2) Lingkup pemasaran usaha (wilayah) menjadi lebih luas; (3) Produk yang dihasilkan menjadi lebih beraneka ragam; (4) Kapasitas (kemampuan) produksi makin berkembang; (5) Jumlah produksi mengalami peningkatan fisik (dalam unit); (6) Laba usaha makin meningkat; (7) Aset usaha makin meningkat; (8) Jumlah tenaga kerja bertambah; dan (9) Kesejahteraan keluarga meningkat. Berdasarkan indikator tersebut, hasil survei tentang output setelah memeroleh dana pinjaman CSR dari PT INKA Persero dapat disajikan pada Tabel 5.

Tabel 5.

Distribusi Jawaban Responden Untuk Efektifitas Output

\begin{tabular}{|c|c|c|c|c|c|c|c|c|c|c|c|}
\hline \multirow{3}{*}{ Indikator } & \multicolumn{10}{|c|}{ Jawaban Responden } & \multirow{3}{*}{$\begin{array}{c}\text { Mea } \\
\text { n }\end{array}$} \\
\hline & \multicolumn{2}{|c|}{ SS } & \multicolumn{2}{|c|}{$\mathbf{S}$} & \multicolumn{2}{|c|}{$\mathrm{CS}$} & \multicolumn{2}{|c|}{ TS } & \multicolumn{2}{|c|}{ STS } & \\
\hline & $\mathbf{F}$ & $\%$ & $\mathbf{F}$ & $\%$ & $\mathbf{F}$ & $\%$ & $\mathbf{F}$ & $\%$ & $\mathbf{F}$ & $\%$ & \\
\hline Usaha menjadi lebih mandiri & 7 & 8 & 67 & 76,1 & 9 & 10,2 & 5 & 5,7 & 0 & 0 & 3,87 \\
\hline $\begin{array}{l}\text { Lingkup pemasaran usaha lebih } \\
\text { luas }\end{array}$ & 9 & 10,2 & 48 & 54,6 & 26 & 29,6 & 4 & 4,6 & 1 & 1,1 & 3,69 \\
\hline $\begin{array}{l}\text { Produk yang dihasilkan lebih } \\
\text { beragam }\end{array}$ & 10 & 11,4 & 47 & 53,4 & 20 & 22,7 & 11 & 12,5 & 0 & 0 & 3,64 \\
\hline $\begin{array}{l}\text { Kapasitas produksi makin } \\
\text { berkembang }\end{array}$ & 10 & 11,4 & 62 & 70,5 & 13 & 14,8 & 3 & 3,4 & 0 & 0 & 3,90 \\
\hline $\begin{array}{l}\text { Jumlah produksi makin } \\
\text { meningkat }\end{array}$ & 9 & 10,2 & 61 & 69,4 & 12 & 13,6 & 6 & 6,8 & 0 & 0 & 3,83 \\
\hline Laba usaha makin meningkat & 6 & 6,8 & 52 & 59,0 & 26 & 29,6 & 4 & 4,6 & 0 & 0 & 3,69 \\
\hline Aset usaha makin meningkat & 6 & 6,8 & 47 & 53,4 & 20 & 22,7 & 15 & 17,1 & 0 & 0 & $\mathbf{3 , 5 0}$ \\
\hline Jumlah tenaga kerja bertambah & 3 & 3,4 & 38 & 43,2 & 21 & 23,8 & 26 & 29,6 & 0 & 0 & 3,21 \\
\hline $\begin{array}{l}\text { Kesejahteraan keluarga } \\
\text { meningkat }\end{array}$ & 9 & 10,2 & 50 & 56,8 & 26 & 29,6 & 3 & 3,4 & 0 & 0 & 3,74 \\
\hline $\begin{array}{l}\text { Mendukung pengembangan } \\
\text { usaha dan bermanfaat }\end{array}$ & 11 & 12,5 & 62 & 70,4 & 15 & 17,1 & 0 & 0 & 0 & 0 & 3,96 \\
\hline
\end{tabular}

Sumber: Data primer diolah, 2016

Deskripsi responden pada Tabel 5 menunjukkan bahwa peningkatan kemandirian usaha memeroleh respon rata-rata sebesar 3,87 yang berarti tanggapan mitra sebagai responden cenderung setuju bahwa setelah memeroleh pinjaman dana CSR dari PT INKA Persero, usaha menjadi lebih mandiri. Indikator perluasan lingkup pemasaran memeroleh respon rata-rata sebesar 3,69 yang berarti tanggapan mitra 


\section{JURNAL EKONOMI DAN MANAJEMEN \\ P-ISSN: 2598-9022/ E-ISSN: 2598-9618 \\ Available at: \\ http://e-journal.unipma.ac.id/index.php/capital}

sebagai responden cenderung setuju bahwa setelah memeroleh pinjaman dana CSR dari PT INKA Persero, lingkup pemasaran usaha menjadi lebih luas. Indikator produk yang dihasilkan lebih beragam memeroleh respon rata-rata sebesar 3,64 yang berarti tanggapan mitra sebagai responden cenderung setuju bahwa setelah memeroleh pinjaman dana CSR dari PT INKA Persero, produk yang dihasilkan lebih beraneka ragam.

Indikator kapasitas produksi makin berkembang memeroleh respon rata-rata sebesar 3,90 yang berarti tanggapan mitra sebagai responden cenderung setuju bahwa setelah memeroleh pinjaman dana CSR dari PT INKA Persero, kapasitas produksi makin berkembang. Indikator jumlah produksi makin meningkat memeroleh respon rata-rata sebesar 3,83 yang berarti tanggapan mitra sebagai responden cenderung setuju bahwa setelah memeroleh pinjaman dana CSR dari PT INKA Persero, kapasitas produksi makin meningkat.

Indikator laba makin meningkat memeroleh respon rata-rata sebesar 3,69 yang berarti tanggapan mitra sebagai responden cenderung setuju bahwa setelah memeroleh pinjaman dana CSR dari PT INKA Persero, laba usaha makin meningkat. Indikator jumlah tenaga kerja makin bertambah memeroleh respon ratarata sebesar 3,21 yang berarti tanggapan mitra sebagai responden cenderung cukup setuju bahwa setelah memeroleh pinjaman dana CSR dari PT INKA Persero, jumlah tenaga kerja bertambah.
Indikator kesejahteraan keluarga makin meningkat memeroleh respon rata-rata sebesar 3,74 yang berarti tanggapan mitra sebagai responden cenderung setuju bahwa setelah memeroleh pinjaman dana CSR dari PT INKA Persero, kesejahteraan keluarga makin meningkat. Indikator mendukung pengembangan usaha dan bermanfaat memeroleh respon rata-rata sebesar 3,96 yang berarti tanggapan mitra sebagai responden cenderung setuju bahwa setelah memeroleh pinjaman dana CSR dari PT INKA Persero, mendukung pengembangan usaha dan dirasakan manfaatnya oleh mitra.

\section{Analisa Kuantitatif}

Untuk mengukur efektifitas output dilakukan analisis efektifitas secara statistik dengan menggunakan Uji Beda Berpasangan (Paired Sample $t$ test) yang membandingkan kondisi UKM mitra binaan sebelum dan sesudah pemberian bantuan dana kemitraan dari PT INKA (Persero).Indikator yang diperbandingkan adalah: pendapatan, laba, jumlah tenaga kerja, kapasitas produksi dan modal kerja. Pengujian menggunakan program SPSS Release 17.

\section{Uji Efektifitas Pendapatan}

Berdasarkan pengujian data yang diperoleh dari kuesioner, diperoleh hasil

uji beda tingkat pendapatan UKM mitra binaan sebagaimana Tabel 6 berikut: 


\section{JURNAL EKONOMI DAN MANAJEMEN \\ P-ISSN: 2598-9022/ E-ISSN: 2598-9618 \\ Available at: \\ http://e-journal.unipma.ac.id/index.php/capital}

Tabel 6. Rata-rata Tingkat Pendapatan

Paired Samples Statistics

\begin{tabular}{|c|c|c|c|c|c|}
\hline & & Mean & $\mathbf{N}$ & $\begin{array}{c}\text { Std. } \\
\text { Deviation }\end{array}$ & $\begin{array}{l}\text { Std. } \\
\text { Error } \\
\text { Mean }\end{array}$ \\
\hline \multirow{2}{*}{$\begin{array}{l}\text { Pair } \\
1\end{array}$} & Sebelum & $1.4531 \mathrm{E} 7$ & 88 & $1.77786 \mathrm{E} 7$ & $1.89520 \mathrm{E} 6$ \\
\hline & Sesudah & $2.5356 \mathrm{E} 7$ & 88 & $2.27740 \mathrm{E} 7$ & $2.42771 \mathrm{E} 6$ \\
\hline
\end{tabular}

Berdasarkan Tabel 6 diketahui bahwa tingkat pendapatan rata-rata usaha kecil mitra binaan sebelum mendapatkan bantuan dana dari PT INKA Persero sebesar Rp 14.531.000,- per tahun. Set5elah mendapatkan bantuan, rata-rata tingkat pendapatan mencapai $\mathrm{Rp}$ 25.356.000,- per tahun. Dengan demikian terdapat peningkatan ratarata tingkat pendapatan usaha kecil mitra binaan setelah mendapatkan bantuan dana dari PT INKA Persero.
Tabel 7. Korelasi Tingkat Pendapatan Sebelum dan Sesudah

\begin{tabular}{|c|c|c|c|c|}
\hline \multicolumn{5}{|c|}{ Paired Samples Correlations } \\
\hline & & & Correla & Signific \\
\hline & & $\mathbf{N}$ & ion & -ance \\
\hline Pair 1 & $\begin{array}{l}\text { Sebelum } \\
\text { dan Sesudah }\end{array}$ & 88 & .691 & .000 \\
\hline
\end{tabular}

Dari Tabel 7 diketahui korelasi antara kedua variabel (sebelum dan sesudah) menghasilkan angka 0,691 dengan nilai probabilitas 0,000 di bawah nilai signifikansi 0,05 .

Hal ini menunjukkan bahwa korelasi antara kondisi tingkat pendapatan sebelum dan sesudah mendapatkan bantuan dana dari PT INKA Persero cukup erat dan berhubungan secara nyata/signifikan.

Tabel 8. Uji Beda Tingkat Pendapatan

\begin{tabular}{|c|c|c|c|c|c|c|c|c|c|}
\hline \multicolumn{10}{|c|}{ Paired Differences } \\
\hline & & \multirow[t]{2}{*}{ Mean } & \multirow{2}{*}{$\begin{array}{c}\text { Std. } \\
\text { Deviation }\end{array}$} & \multirow{2}{*}{$\begin{array}{c}\text { Std. } \\
\text { Error } \\
\text { Mean }\end{array}$} & \multicolumn{2}{|c|}{$\begin{array}{l}\text { 95\% Confidence Interval } \\
\text { of the Difference }\end{array}$} & \multirow[t]{2}{*}{$\mathbf{t}$} & \multirow[t]{2}{*}{ Df } & \multirow[t]{2}{*}{$\begin{array}{c}\text { Sig. } \\
\text { (2tailed) }\end{array}$} \\
\hline & & & & & Lower & Upper & & & \\
\hline \multirow[t]{2}{*}{ Pair 1} & Sebelum & & & & & & & & \\
\hline & Sesudah & $-1.0824 \mathrm{E} 7$ & $1.6585 \mathrm{E} 7$ & $1.7679 \mathrm{E} 6$ & $-1.43385 \mathrm{E} 7$ & $-7.31036 \mathrm{E} 6$ & -6.122 & 87 & .000 \\
\hline
\end{tabular}

Berdasarkan Tabel 8 diketahui bahwa tingkat signifikansi (Sig. 2 tailed) sebesar 0.000, lebih kecil dari nilai signifikansi $\alpha 0,05$ yang berarti rata-rata tingkat pendapatan sebelum dan sesudah adalah berbeda. Hal ini menunjukkan bahwa rata-rata tingkat pendapatan mitra binaan sebelum dan sesudah mendapatkan dana bantuan dari PT INKA adalah berbeda (meningkat) signifikan.
Tabel 9. Rata-Rata Laba

\begin{tabular}{|c|c|c|c|c|c|}
\hline \multicolumn{6}{|c|}{ Paired Samples Statistics } \\
\hline & & Mean & $\mathbf{N}$ & $\begin{array}{c}\text { Std. } \\
\text { Deviation }\end{array}$ & $\begin{array}{c}\text { Std. Error } \\
\text { Mean }\end{array}$ \\
\hline \multirow[t]{2}{*}{ Pair 1} & Sebelum & $4.2759 \mathrm{E} 6$ & 86 & 5.37967E6 & $5.80104 \mathrm{E} 5$ \\
\hline & Sesudah & $8.9878 \mathrm{E} 6$ & 86 & $1.07651 \mathrm{E} 7$ & $1.16083 \mathrm{E} 6$ \\
\hline
\end{tabular}

Sumber: Hasil Olah Data SPSS, 2016

Berdasarkan Tabel 9 diketahui bahwa laba rata-rata usaha kecil mitra binaan sebelum mendapatkan bantuan dana dari PT INKA Persero sebesar Rp 4.275.900,- per tahun. Sesudah mendapatkan bantuan, rata- 


\section{JURNAL EKONOMI DAN MANAJEMEN \\ P-ISSN: 2598-9022/ E-ISSN: 2598-9618 \\ Available at:}

http://e-journal.unipma.ac.id/index.php/capital

rata laba mencapai $\mathrm{Rp}$ 8.987.000,per tahun.

Dengan demikian terdapat peningkatan rata-rata laba usaha kecil mitra binaan.

Tabel 10. Korelasi Laba Sebelum dan Sesudah

\begin{tabular}{|c|c|c|c|c|}
\hline \multicolumn{5}{|c|}{ Paired Samples Correlations } \\
\hline & & $\mathbf{N}$ & Correlation & Sig. \\
\hline $\begin{array}{l}\text { Pair } \\
1\end{array}$ & $\begin{array}{l}\text { Sebelum } \\
\text { - Sesudah }\end{array}$ & 86 & .680 & .000 \\
\hline
\end{tabular}

Sumber: Hasil Olah Data SPSS, 2016
Dari Tabel 10 diketahui hasil korelasi antara kedua variabel (sebelum dan sesudah), menghasilkan angka 0,680 dengan nilai probabilitas 0,000 di bawah nilai signifikansi $\alpha 0,05$.

Hal ini menunjukkan bahwa korelasi antara laba sebelum dan sesudah mendapatkan bantuan dari PT INKA Persero cukup erat dan berhubungan secara nyata/signifikan.

Tabel 11. Uji Beda Laba

\begin{tabular}{|c|c|c|c|c|c|c|c|c|c|}
\hline & & \multicolumn{5}{|c|}{ Paired Samples Test } & \multirow{4}{*}{$\mathbf{t}$} & \multirow{4}{*}{ Df } & \multirow{4}{*}{$\begin{array}{l}\text { Sig. } \\
(2- \\
\text { tailed })\end{array}$} \\
\hline & & & & aired Diff & ences & & & & \\
\hline & & \multirow[t]{2}{*}{ Mean } & \multirow[t]{2}{*}{$\begin{array}{c}\text { Std. } \\
\text { Deviation }\end{array}$} & \multirow[t]{2}{*}{$\begin{array}{l}\text { Std. } \\
\text { Error } \\
\text { Mean }\end{array}$} & \multicolumn{2}{|c|}{$\begin{array}{c}95 \% \text { Confidence } \\
\text { Interval of the } \\
\text { Difference } \\
\end{array}$} & & & \\
\hline & & & & & Lower & Upper & & & \\
\hline Pair 1 & $\begin{array}{l}\text { Sebelum } \\
\text {-Sesudah }\end{array}$ & $-4.71192 \mathrm{E} 6$ & $8.1259 \mathrm{E} 6$ & 8.7624E5 & $-6.45412 \mathrm{E} 6$ & $-2.96972 \mathrm{E} 6$ & -5.38 & 85 & .000 \\
\hline
\end{tabular}

Sumber: Hasil Olah Data SPSS, 2016

Berdasarkan Tabel 11 diketahui bahwa tingkat signifikansi (Sig. 2 tailed) sebesar 0.000, lebih kecil dari nilai signifikansi $\alpha_{0,05}$ yang berarti rata-rata laba sebelum dan sesudah adalah berbeda.

Hal ini menunjukkan bahwa rata-rata laba mitra binaan sebelum dan sesudah mendapatkan dana bantuan dari PT INKA Persero berbeda signifikan.

\section{Uji Efektifitas Jumlah Tenaga Kerja}

Tabel 12. Rata-rata Jumlah Tenaga Kerja

\begin{tabular}{cccccc}
\hline \multicolumn{6}{c}{ Paired Samples Statistics } \\
\hline & Mean & N & $\begin{array}{c}\text { Std. } \\
\text { Deviation }\end{array}$ & $\begin{array}{c}\text { Std. } \\
\text { Error } \\
\text { Mean }\end{array}$ \\
\hline $\begin{array}{c}\text { Pair } \\
1\end{array}$ & Sebelum & 4.6023 & 88 & 4.70397 & .50145 \\
& Sesudah & 5.9091 & 88 & 5.00491 & .53353 \\
\hline
\end{tabular}

Sumber: Hasil Olah Data SPSS, 2016

Berdasarkan Tabel 12 diketahui bahwa rata-rata jumlah tenaga kerja mitra

binaan sebelum mendapatkan bantuan dana dari PT INKA Persero sebanyak 4,6 atau 5 orang. Sesudah mendapatkan bantuan, rata-rata jumlah tenaga kerja menjadi 5,9 atau 6 orang. Dengan demikian terdapat 


\section{JURNAL EKONOMI DAN MANAJEMEN \\ P-ISSN: 2598-9022/ E-ISSN: 2598-9618 \\ Available at: \\ http://e-journal.unipma.ac.id/index.php/capital}

peningkatan rata-rata jumlah tenaga kerja usaha kecil mitra binaan setelah mendapatkan bantuan dana dari PT INKA Persero.

\begin{tabular}{|c|c|c|c|c|}
\hline \multicolumn{5}{|c|}{$\begin{array}{c}\text { Tabel 13. Korelasi Jumlah Tenaga } \\
\text { Kerja Sebelum dan Sesudah } \\
\text { Paired Samples Correlations }\end{array}$} \\
\hline & & $\mathbf{N}$ & $\begin{array}{c}\text { Correl } \\
\text { ation }\end{array}$ & Sig. \\
\hline Pair 1 & $\begin{array}{l}\text { Sebelum - } \\
\text { Sesudah }\end{array}$ & 88 & .876 & .000 \\
\hline
\end{tabular}

Sumber: Hasil Olah Data SPSS, 2016
Dari Tabel 13 diketahui korelasi antara kedua variabel (sebelum dan sesudah) menghasilkan angka 0,876 dengan nilai probabilitas 0,000 di bawah nilai signifikansi 0,05 . Hal ini menunjukkan bahwa korelasi antara jumlah tenaga kerja sebelum dan sesudah mendapatkan bantuan dari PT INKA Persero sangat erat dan berhubungan secara nyata/ signifikan.

Tabel 14. Uji Beda Jumlah Tenaga Kerja

\begin{tabular}{|c|c|c|c|c|c|c|c|c|c|}
\hline \multicolumn{10}{|c|}{ Paired Samples Test } \\
\hline & & \multicolumn{5}{|c|}{ Paired Differences } & \multirow{3}{*}{$\mathbf{t}$} & \multirow{3}{*}{ Df } & \multirow{3}{*}{$\begin{array}{l}\text { Sig. } \\
(2- \\
\text { tailed) }\end{array}$} \\
\hline & & \multirow[t]{2}{*}{ Mean } & \multirow[t]{2}{*}{$\begin{array}{c}\text { Std. } \\
\text { Deviation }\end{array}$} & \multirow[t]{2}{*}{$\begin{array}{l}\text { Std. Error } \\
\text { Mean }\end{array}$} & \multicolumn{2}{|c|}{$\begin{array}{l}\text { 95\% Confidence } \\
\text { Interval of the } \\
\text { Difference }\end{array}$} & & & \\
\hline & & & & & Lower & Upper & & & \\
\hline Pair 1 & $\begin{array}{l}\text { Sebelum- } \\
\text { Sesudah }\end{array}$ & -1.3068 & 2.43234 & .25929 & -1.8221 & -.7915 & -5.04 & 87 & .000 \\
\hline
\end{tabular}

Sumber: Hasil Olah Data SPSS, 2016

Berdasarkan Tabel 14 diketahui bahwa tingkat signifikansi sebesar 0.000, lebih kecil dari nilai signifikansi $\alpha_{0,05}$ yang berarti ratarata jumlah tenaga kerja sebelum dan sesudah adalah berbeda. Hal ini menunjukkan bahwa jumlah tenaga kerja mitra binaan sebelum mendapatkan dana bantuan berbeda signifikan dengan sesudahnya (meningkat).

\section{Uji Efektifitas Kapasitas Produksi}

Berdasarkan pengujian data yang diperoleh dari kuesioner, diperoleh hasil uji beda besarnya kapasitas produksi UKM mitra binaan sebagai berikut:
Tabel 15. Rata-Rata Kapasitas Produksi

\begin{tabular}{|c|c|c|c|c|c|}
\hline \multicolumn{6}{|c|}{ Paired Samples Statistics } \\
\hline & & Mean & $\mathbf{N}$ & $\begin{array}{c}\text { Std. } \\
\text { Deviatio } \\
\text { n }\end{array}$ & $\begin{array}{l}\text { Std. } \\
\text { Error } \\
\text { Mean }\end{array}$ \\
\hline \multirow[t]{2}{*}{$\begin{array}{c}\text { Pair } \\
1\end{array}$} & $\begin{array}{l}\text { Sebe } \\
\text { lum }\end{array}$ & 623.9589 & 73 & 1038.92129 & 121.59654 \\
\hline & $\begin{array}{c}\text { Sesu } \\
\text { dah }\end{array}$ & 864.2219 & 73 & 1348.60806 & 157.84263 \\
\hline
\end{tabular}

Sumber: Hasil Olah Data SPSS, 2016

Berdasarkan Tabel 15 diketahui bahwa kapasitas produksi rata-rata usaha mitra binaan sebelum mendapatkan bantuan dana adalah sebesar 623,9589 satuan. Sesudah mendapatkan bantuan, rata-rata kapasitas produksi mencapai 864,2219 satuan. Dengan demikian 


\section{JURNAL EKONOMI DAN MANAJEMEN \\ P-ISSN: 2598-9022/ E-ISSN: 2598-9618 \\ Available at:}

http://e-journal.unipma.ac.id/index.php/capital

terdapat peningkatan rata-rata kapasitas produksi usaha kecil mitra binaan.

Tabel 16. Korelasi Kapasitas Produksi Sebelum dan Sesudah Paired Samples Correlations

\begin{tabular}{|c|c|c|c|c|}
\hline & & $\mathbf{N}$ & $\begin{array}{l}\text { Cor } \\
\text { rela } \\
\text { tion }\end{array}$ & Sig. \\
\hline $\begin{array}{c}\text { Pair } \\
1\end{array}$ & $\begin{array}{l}\text { Sebelum - } \\
\text { Sesudah }\end{array}$ & 73 & .921 & .000 \\
\hline
\end{tabular}

Dari Tabel 16 diketahui bahwa
korelasi antara kedua variabel
(sebelum dan sesudah) menghasilkan
angka 0,921 dengan nilai probabilitas
0,000 di bawah nilai signifikansi
0,05 . Hal ini menunjukkan bahwa
korelasi antara kapasitas produksi
sebelum dan sesudah mendapatkan
bantuan dana sangat erat dan
berhubungan signifikan.

Tabel 17. Uji Beda Kapasitas Produksi

\begin{tabular}{|c|c|c|c|c|c|c|c|c|c|}
\hline \multicolumn{10}{|c|}{ Paired Samples Test } \\
\hline & & \multicolumn{5}{|c|}{ Paired Differences } & \multirow{3}{*}{$\mathbf{t}$} & \multirow{3}{*}{ Df } & \multirow{3}{*}{$\begin{array}{l}\text { Sig } \\
(2- \\
\text { tail } \\
\text { d) }\end{array}$} \\
\hline & & \multirow[t]{2}{*}{ Mean } & \multirow{2}{*}{$\begin{array}{c}\text { Std. } \\
\text { Deviation }\end{array}$} & \multirow{2}{*}{$\begin{array}{c}\text { Std. } \\
\text { Error } \\
\text { Mean }\end{array}$} & \multicolumn{2}{|c|}{$\begin{array}{l}\text { 95\% Confidence Interval of } \\
\text { the Difference }\end{array}$} & & & \\
\hline & & & & & Lower & Upper & & & \\
\hline Pair 1 & $\begin{array}{l}\text { Sebelum - } \\
\text { Sesudah }\end{array}$ & -240.263 & 562.5498 & 65.84148 & -371.516 & -109.010 & -3.65 & 72 & .000 \\
\hline
\end{tabular}

Sumber: Hasil Olah Data SPSS, 2016

Berdasarkan Tabel 17 diketahui bahwa tingkat signifikansi sebesar 0.000, lebih kecil dari nilai signifikansi $\alpha_{0,05}$ yang berarti ratarata kapasitas produksi sebelum dan sesudah adalah berbeda. Hal ini menunjukkan bahwa rata-rata kapasitas produksi mitra binaan sebelum dan sesudah mendapatkan dana bantuan dari PT INKA adalah berbeda (meningkat) signifikan.

\section{Uji Efektifitas Modal Kerja}

Berdasarkan pengujian data yang diperoleh dari kuesioner, diperoleh hasil uji beda modal kerja UKM mitra binaan sebagai berikut:

Tabel 18. Rata-rata Modal Kerja

Paired Samples Statistics

\begin{tabular}{cccccc}
\hline & & Mean & N & Std. Deviation & $\begin{array}{c}\text { Std. Error } \\
\text { Mean }\end{array}$ \\
\hline Pair & Sebelum & $1.3499 \mathrm{E} 7$ & 88 & $1.70673 \mathrm{E} 7$ & $1.81938 \mathrm{E} 6$ \\
1 & Sesudah & $2.8069 \mathrm{E} 7$ & 88 & $3.05927 \mathrm{E} 7$ & $3.26119 \mathrm{E} 6$ \\
\hline
\end{tabular}

Sumber: Hasil Olah Data SPSS, 2016 


\section{JURNAL EKONOMI DAN MANAJEMEN \\ P-ISSN: 2598-9022/ E-ISSN: 2598-9618 \\ Available at:}

http://e-journal.unipma.ac.id/index.php/capital

Berdasarkan Tabel 18 diketahui bahwa modal kerja rata-rata usaha kecil mitra binaan sebelum mendapatkan bantuan dana adalah sebesar Rp 13.499.000,-. Sesudah mendapatkan bantuan dana dari PT INKA, rata-rata modal kerja meningkat menjadi Rp 28.069.000,--

Dengan demikian terdapat peningkatan rata-rata modal kerja usaha kecil mitra binaan.
Tabel 19. Korelasi Modal Kerja Sebelum dan Sesudah

Paired Samples Correlations

\begin{tabular}{clccc}
\hline & & $\mathbf{N}$ & $\begin{array}{c}\text { Correl } \\
\text { ation }\end{array}$ & Sig. \\
\hline Pair 1 & $\begin{array}{l}\text { Sebelum - } \\
\text { Sesudah }\end{array}$ & 88 & .623 & .000 \\
\hline Sumb & & & \\
\hline
\end{tabular}

Sumber: Hasil Olah Data SPSS, 2016

Berdasarkan Tabel 19 diketahui bahwa korelasi antara kedua variabel (sebelum dan sesudah) menghasilkan angka 0,623 dengan nilai probabilitas 0,000 di bawah nilai signifikansi 0,05 . Hal ini menunjukkan bahwa korelasi antara modal kerja sebelum dan sesudah mendapatkan bantuan dana dari PT INKA cukup erat dan berhubungan secara nyata/signifikan.

Tabel 20. Uji Beda Modal Kerja

\begin{tabular}{|c|c|c|c|c|c|c|c|c|c|}
\hline \multicolumn{10}{|c|}{ Paired Samples Test } \\
\hline & & \multicolumn{5}{|c|}{ Paired Differences } & \multirow{3}{*}{$\mathbf{t}$} & \multirow{3}{*}{ Df } & \multirow{3}{*}{$\begin{array}{l}\text { Sig.2ta } \\
\text { ild }\end{array}$} \\
\hline & & \multirow[t]{2}{*}{ Mean } & \multirow[t]{2}{*}{$\begin{array}{c}\text { Std. } \\
\text { Deviation }\end{array}$} & \multirow{2}{*}{$\begin{array}{c}\text { Std. } \\
\text { Error } \\
\text { Mean }\end{array}$} & \multicolumn{2}{|c|}{$\begin{array}{l}\text { 95\% Confidence Interval of the } \\
\text { Difference }\end{array}$} & & & \\
\hline & & & & & Lower & Upper & & & \\
\hline $\begin{array}{l}\text { Pair } \\
1\end{array}$ & $\begin{array}{l}\text { Sebelum } \\
\text { Sesudah }\end{array}$ & $-1.457 \mathrm{E} 7$ & $2.4019 \mathrm{E} 7$ & $2.561 \mathrm{E} 6$ & $-1.9659 \mathrm{E} 7$ & $-9.48108 \mathrm{E} 6$ & -5.7 & 87 & .000 \\
\hline
\end{tabular}

\section{Berdasarkan Tabel 20} diketahui bahwa tingkat signifikansi (Sig. 2 tailed) sebesar 0.000, lebih kecil dari nilai signifikansi $\alpha_{0,05}$ yang berarti rata-rata modal kerja sebelum dan sesudah adalah berbeda. Hal ini menunjukkan bahwa rata-rata modal kerja mitra binaan sebelum dan sesudah mendapatkan dana dari PT INKA berbeda secara signifikan.

\section{SIMPULAN DAN SARAN}

Ketentuan pelaksanaan Program Kemitraan di PT INKA (Persero) diatur dalam Keputusan Direksi PT Industri Kereta Api (Persero) Nomor:
07/SK/INKA/2012 tentang Pedoman Program Kemitraan dan Bina Lingkungan. Selanjutnya Keputusan Direksi tersebut diperbaharui dengan Peraturan Direksi PT Industri Kereta Api (Persero) Nomor: PER 03//INKA/2015 tentang Program Kemitraan dan Bina Lingkungan PT Industri Kereta Api (Persero). Peraturan dimaksud dibuat berdasarkan Peraturan Menteri BUMN yang senantiasa disempurnakan terus untuk disesuaikan dengan perkembangan dan kebutuhan. 


\section{JURNAL EKONOMI DAN MANAJEMEN \\ P-ISSN: 2598-9022/ E-ISSN: 2598-9618 \\ Available at: \\ http://e-journal.unipma.ac.id/index.php/capital}

Hasil penelitian memberikan gambaran bahwa mitra binaan PT INKA (Persero) yang telah mendapatkan bantuan CSR menyatakan bahwa syarat administrasi untuk mendapatkan bantuan tersebut mudah dan tidak berbelit. Persyaratan administratif telah diatur melalui Peraturan Direksi. Implementasi program kemitraan PT INKA (Persero) menurut mitra binaan sudah berjalan efektif. Keadaan yang demikian memberikan gambaran bahwa mitra binaan sudah merasakan bahwa :

1) Sosialisasi Program Kemitraan oleh PT INKA Persero kepada mitra binaan memberi kejelasan hak dan kewajiban masingmasing pihak. Hal ini sangat membantu mitra untuk mengetahui posisinya sehingga bisa saling menjaga peran dan posisi masing-masing.

2) Mitra binaan dilibatkan dalam proses penyaluran dana CSR oleh PT INKA Persero. Keterlibatan ini dirasakan manfaatnya oleh mitra karena mengetahui secara langsung bagaimana proses penyaluran itu dilakukan, sehingga transparansi dan keterbukaan bisa terjaga, terhindar dari budaya 'kongkalikong'. Mitra binaan juga merasa dihargai.

3) Sosialisasi Program Kemitraan oleh PT INKA Persero kepada mitra binaan dirasakan bermanfaat oleh mitra. Dengan intensifnya sosialisasi, makin banyak calon mitra dan makin kompetitif dalam mengusulkan dana pinjaman bergulir.
4) Syarat administrasi untuk mendapatkan bantuan dana CSR dari PT INKA (Persero) dirasakan mudah oleh mitra binaan, karena syarat yang ditentukan mudah dipenuhi. Hal ini sangat membantu usaha kecil yang selama ini sering mengalami kendala untuk mengakses lembaga perbankan atau lembaga keuangan lain karena sulit memenuhi beberapa persyaratan antara lain dalam hal agunan, laporan keuangan yang akuntabel atau sesuai standar akuntansi yang berlaku. Persyaratan untuk mendapatkan bantuan berupa pinjaman telah diatur dalam Keputusan Direksi PT Industri Kereta Api (Persero) Nomor : $\quad 07 / S K / I N K A / 2012$, khususnya pasal 9.

5) Penyaluran bantuan CSR oleh PT INKA (Persero) kepada mitra binaan dirasakan sudah tepat pada pihak yang membutuhkan. Bantuan CSR benar-benar bermanfaat untuk menjalankan operasional atau pengembangan usaha. Nilai atau nominal bantuan didasarkan pada hasil evaluasi berdasarkan proposal dan hasil survei, sehingga pinjaman yang diperoleh tergantung pada permohonan dan kinerja mitra binaan.

6) Penyaluran bantuan CSR oleh PT INKA (Persero) kepada mitra binaan dirasakan cepat / lancar. Kelancaran pencairan dana membantu mitra binaan segera memanfaatkan untuk menambah modal kerja ataupun pembelian peralatan yang dibutuhkan. Namun ada sebagian kecil dari 


\section{JURNAL EKONOMI DAN MANAJEMEN \\ P-ISSN: 2598-9022/ E-ISSN: 2598-9618 \\ Available at: \\ http://e-journal.unipma.ac.id/index.php/capital}

pengusaha makanan dan minuman yang menyatakan penyaluran kurang lancar. Hal ini dimungkinkan karena pengusaha makanan dan minuman yang jumlahnya relatif banyak, akan memerlukan waktu evaluasi dan seleksi yang lebih lama. Tahapan pemberian pinjaman diatur dalam Keputusan Direksi PT Industri Kereta Api (Persero) Nomor : 07/SK/INKA/2012, khususnya pasal 9. Tahapan cukup panjang, diawali pengajuan proposal disertai dokemen pendukung sesuai ketentuan, selanjutnya dilakukan evaluasi, survei lapangan, evaluasi berdasarkan proposal dan hasil survei. Proposal yang memenuhi kelayakan selanjutnya diajukan ke Direksi; bagi mitra yang mendapat persetujuan selanjutnya diwawancarai dengan mengikutsertakan suami/istri atau ketua dan bendahara usaha kecil sebagai wujud ikatan tanggung jawab bersama. Apabila calon mitra binaan telah menyatakan kesediaan atas bentuk kemitraan dan/atau jumlah dana yang diberikan maka dibuat Surat Perjanjian Kemitraan yang harus ditandatangani. Selanjutnya mitra binaan yang telah mendapatkan persetujuan harus mengajukan permohonan pencairan dana kemitraan. Pencairan dana dilakukan melalui bank yang ditunjuk. Tahapan yang panjang tersebut merupakan sistem yang dibangun PT INKA (Persero) agar program kemitraan dapat berjalan aman dan efektif.
7) Pelatihan untuk pengembangan usaha mitra binaan oleh PT INKA (Persero) dirasakan bermanfaat. Namun masih ada mitra yang berpendapat bahwa pelatihan tidak memberikan manfaat. Kondisi demikian dapat dimaklumi karena kegiatan usaha mitra binaan beraneka ragam. Ketidaksetujuan bisa disebabkan karena mitra pernah menerima pelatihan yang tidak sesuai kebutuhan. Pelatihan harus dirancang dapat mengakomodasi berbagai kebutuhan mitra binaanyang bersifat umum dan spesifik.

8) Pendampingan oleh PT INKA (Persero) dirasakan membantu untuk pengembangan usaha mitra binaan. Namun ada yang menyatakan bahwa pendampingan tidak membantu pengembangan usaha. Hal ini bisa terjadi apabila pendampingan justru dianggap sebagai bentuk intervensi atau mengganggu kegiatan operasional mitra binaan.

9) Akses komunikasi yang diberikan oleh PT INKA (Persero) kepada mitra binaan selama periode/masa pinjaman sangat terbuka. Hal ini dilakukan agar semua permasalahan dapat dikomunikasikan dengan cepat untuk mendapatkan penyelesaian. Dengan demikian risiko kegagalan kegiatan usaha mitra binaan yang mendapat bantuan maupun risiko kemacetan pembayaran dapat dihindari. Namun demikian masih ada mitra binaan yang merasa kurang 


\section{JURNAL EKONOMI DAN MANAJEMEN \\ P-ISSN: 2598-9022/ E-ISSN: 2598-9618 \\ Available at: \\ http://e-journal.unipma.ac.id/index.php/capital}

mendapatkan akses komunikasi dengan PT INKA (Persero).

10) Kondisi piutang kepada mitra binaan (MB) berdasarkan sektor dan kualitas pengembalian dengan predikat: lancar, kurang lancar, diragukan dan macet) sampai dengan tahun 2015 ditunjukkan dalam Tabel 21 sebagai berikut :

Tabel 21. Kondisi dan Kualitas Pengembalian Piutang Mitra Binaan (MB) Sampai dengan Tahun 2015

\begin{tabular}{clcccr}
\hline \multirow{2}{*}{ NO } & \multirow{2}{*}{ KATEGORI } & \multicolumn{2}{c}{ SEKTOR INDUSTRI } & \multicolumn{2}{c}{ SEKTOR PERDAGANGAN } \\
\cline { 3 - 6 } & & Jumlah MB & NILAI (Rp) & $\begin{array}{c}\text { Jumlah } \\
\text { MB }\end{array}$ & \multicolumn{1}{c}{ NILAI (Rp) } \\
\hline 1 & Lancar & 159 & $2.504 .177 .123,00$ & 18 & $274.482 .131,00$ \\
2 & Kurang lancar & 24 & $318.525 .773,00$ & 0 & 0 \\
3 & Diragukan & 5 & $70.693 .646,00$ & 1 & $7.544 .056,00$ \\
4 & Macet & 90 & $745.541 .490,00$ & 3 & $51.944 .385,00$ \\
\hline & Total & $\mathbf{2 7 8}$ & $\mathbf{3 . 6 3 8 . 9 3 8 . 0 3 2 , 0 0}$ & $\mathbf{2 2}$ & $\mathbf{3 3 3 . 9 7 0 . 5 7 2 , 0 0}$
\end{tabular}

Sumber : Laporan Pelaksanaan PKBL PTINKA (Persero) Tahun 2015

Dari Tabel 21 diketahui bahwa pengembalian piutang dari mitra binaan di sektor industri sebesar 57 persen lancar, yang macet sebesar 32 persen. Sedangkan pengembalian di sektor perdagangan, sebesar 82 persen lancar, yang macet hanya sebesar 14 persen. Terjadinya pengembalian piutang tidak lancar (kurang lancar, diragukan, macet) adalah disebabkan sebagai berikut :

- Karakter mitra binaan kurang baik dalam menyelesaikan hutang yang telah jatuh tempo

- Usaha mitra binaan mengalami penurunan usaha atau sudah tidak ada usaha (bangkrut)

- Mitra binaan meninggal dunia, namun ahli waris tidak mau bertanggung jawab atau tidak mampu untuk menyelesaikan hutang piutang tersebut.
- Mitra binaan pindah alamat dan tidak diketahui keberadaannya tanpa memberitahu lingkungan setempat.

- Terjadi ketidakharmonisan rumah tangga sehingga saling melempar tanggung jawab penyelesaian hutang.

- Tidak adanya klausul dalam perjanjian dengan mitra binaan tentang kuasa untuk menjual jaminan apabila terjadi kelalaian dalam membayar angsuran.

11) Kesempatan konsultasi yang diberikan oleh PT INKA kepada mitra binaan tentang pengembangan usaha selama periode/masa pinjaman terbuka lebar. Hal itu disetujui/diakui hampir semua mitra binaan. Hal itu dilakukan agar semua mitra 


\section{JURNAL EKONOMI DAN MANAJEMEN \\ P-ISSN: 2598-9022/ E-ISSN: 2598-9618 \\ Available at: \\ http://e-journal.unipma.ac.id/index.php/capital}

binaan dapat melaksanakan kegiatan usaha secara baik dan profesional, sehingga mitra binaan dapat berkembang dengan cepat dan mandiri.

\section{Saran}

Dari hasil simpulan di atas, beberapa saran kepada PT INKA Persero sebagai berikut:

1. Hendaknya PT INKA Persero menjadikan program mitra binaan menjadi program utama mengingat keadaan masyarakat sekitar perusahaan masih membutuhkan suntikan modal untuk penguatan usaha.

2. Dalam pelaksanaan CSR, PT INKA Persero hendaknya menetapkan mekanisme serta pemantauan secara berkala, jelas dan transparan sehingga masyarakat dapat memonitor kegiatan tersebut.

3. Melibatkan institusi pendidikan untuk melakukan pendampingan bagi mitra binaan.

4. Pelatihan usaha secara rutin dilakukan oleh PT INKA Persero dengan bekerja sama dengan dinas/instansi/lembaga terkait untuk penguatan usaha mitra

5. Perlu dibuat program-program yang dapat memberikan manfaat lebih bagi kelangsungan lingkungan dan masyarakat. Hal ini dilakukan agar tanggung jawab sosial dapat memberikan manfaat bukan hanya kepada perusahaan semata tetapi juga kepada lingkungan dan masyarakat sekitar.

\section{DAFTAR PUSTAKA}

Asy'ari, Hasan. 2008. "Implementasi CSR sebagai Modal Sosial pada PT Newmont", Thesis. Universitas Diponegoro Semarang.

Besse Asniwaty. 2010. Evaluasi Pelaksanaan CSR PT. Pupuk Kaltim. Jurnal Eksis.Vol. 6 No.1 Maret 2010.

Greenley, Hooley, Broderick \& Rudd. 2014. Strategic Planning Differences among Different Multiple Stakeholder Orientation Profiles. Journal of Strategic Marketing, September 2014, pp: 163-182.

Gunawan, Barbara dan Suharti SU. 2008. Peranan CSR dalam Nilai Perusahaan.Jurnal Akuntansi dan Keuangan. Vol.7 Nomor 2, September 2008, hal. 174-185.

Hadi, Pramono. 2013. Community Empowerment through Corporate Social Responsibility in Holcim. International Journal of Scientitic Research and Education. Volume.1 ,Issue.2, Pages.33-37.

Hopkins and Hopkins .2007. Strategic Planning - Financial Performance Relationship in Bank: A Casual Examination, Strategic Management Journal, Vol. 18, pp: 635-652.

Keputusan Direksi PT Industri Kereta Api (Persero) Nomor 16/SK/INKA/2015 tentang 


\section{JURNAL EKONOMI DAN MANAJEMEN \\ P-ISSN: 2598-9022/ E-ISSN: 2598-9618 \\ Available at: \\ http://e-journal.unipma.ac.id/index.php/capital}

Perubahan Ketiga Atas

Keputusan Direksi Nomor 06/SK/INKA/2014 Tentang Struktur Organisasi PT Industri Kereta Api (Persero).

Lee, 2008, Effects to an organizational-level analysis of CSR and its impact on organizational processes and performance, International Journal of Management Review, Vol.3 No.1 Juni 2008 p.22.

Mapasangka, Andi. 2009 .'Implementasi CSR terhadap Kesejahteraan Hidup Masyarakat", Jurnal Ekonomi dan Studi Pembangunan Vol.1 No.1 hal. 39-47.

Marten H. Jean, dkk, Corporate Social Responsibility Perusahaan Multinasional kepada Masyarakat Sekitar: Studi Kasus, Jurnal Usahawan Nomor 03Tahun XXXVI Maret 2007, Universitas Kristen Satya Wacana, Salatiga.

Megawati Cheng dan Yulius JC. 2011. Pengaruh Pengungkapan CSR terhadap Abnormal Return.Jurnal Akuntansi dan Keuangan Vol.13 No.1 hal. 2436.

Mulyadi, Dedi, Sonny Hersona dan Linda Devis May. 2012. Analisis Pelaksanaan CSR pada Pertamina Gas Area JBB Distrik Cilamaya bagi Masyarakat.Jurnal
Manajemen.Vol.09 No.04 Juli 2012 hal. 900-919.

Partini. 2013. CSR dan Pemberdayaan Masyarakat (Studi Implementasi CSR-PTBA di Muara Enim, Sumatra Selatan. Jurnal Manusia dan Lingkungan.Vol.20,No.1,Maret

Peraturan Direksi PT Industri Kereta Api (Persero) Nomor PER 03/INKA/2015 tentang Program Kemitraan dan Bina LingkunganPT Industri Kereta Api (Persero).

Peraturan Menteri Negara BUMN Nomor Per-07/MBU/05/2015 tentang Program Kemitraan BUMN dengan Usaha Kecil dan Program Bina Lingkungan (PKBL).

Prayogo, Dody. 2013. Measuring Corporate Social Responsibility for Local Communities in Mining, Oil and Gas Industries, The Case of Indonesia. Journal of Economics and Sustainable Development. Vol.4,No.1,2013.

Putra, Anggara Satria, 2015, Pengaruh CSR Terhadap Profitabilitas Perusahaan, Jurnal Nominal Vol.IV Nomor $2,2015$.

Rahmayanti, Dian Rhesa. 2012. Strategi Komunikasi dan Corporate Social Responsibility (CSR) (Studi Tentang Strategi Komunikasi dalam Implementasi Progam CSR dan PKBL 
PT KAI (Persero) DAOP VI

Yogyakarta Tahun 2011

Terhadap Pembentukan Citra

Perusahaan). Jurnal Akuntabilitas Vol. 9 Nomor 2 Tahun 2012.

Rudito, Bambang dan Melia Famiola. 2013. Corporate Social Responsibility. Bandung: Penerbit Rekayasa Sains.

Siregar, Chairil N. 2007. Analisis Sosiologis Terhadap Implementasi Corporate Social Responsibility pada Masyarakat Indonesia. Jurnal Sosioteknologi ITB. Vol.6 No.12 Tahun 2007

Sri Urip, 2014, Strategi CSR (Tanggung Jawab Sosial Perusahaan) untuk Peningkatan Daya Saing Perusahaan di Pasar Negara Sedang Berkembang, Jakarta: Penerbit Lentera Hati

Undang-Undang Republik Indonesia Nomor 40 Tahun 2007 tentang Perseroan Terbatas.

Vegawati, S.Mira dan Srikandi Kumadji. 2015. Pengaruh Program Corporate Social Responsibility Terhadap Citra Perusahaan. Jurnal Administrasi Bisnis Vol.20 Nomor 1 Maret 2015. 